neofilolog

Czasopismo Polskiego Towarzystwa Neofilologicznego

ISSN 1429-2173, 2018, NR 51/1, 109-122

http://dx.doi.org/10.14746/n.2018.51.1.8

http://poltowneo.org/

Małgorzata Niemiec-Knaś

Uniwersytet Humanistyczno-Przyrodniczy im. Jana Długosza w Częstochowie, Instytut Filologii Obcych

https://orcid.org/0000-0001-8760-3143

m.niemiec-knas@ajd.czest.pl

\title{
INTERDYSCYPLINARNY CHARAKTER NAUCZANIA JĘZYKA NIEMIECKIEGO A ZDOBYCIE KOMPETENCJI W DRUGIM PRZEDMIOCIE JAKO SZANSA DLA NAUCZYCIELA JĘZYKA OBCEGO DRUGIEGO NA RYNKU PRACY
}

\author{
Interdisciplinary approach to teaching German and the acquisition of \\ competence in second subject teaching as a chance for \\ a second foreign language teacher in the job market
}

The current perspective of teaching German as a second or foreign language is very important in the context of teacher education reform. This article addresses the questions associated with the notion of interdisciplinarity in foreign language teaching and teacher education. The key question is how to prepare foreign language teachers for the difficult labor market. Two aspects are relevant to a future German teacher: one is professional knowledge on teaching German as a foreign language, the second is the knowledge and ability of teaching the second school subject.

Keywords: the teaching German as a second or foreign language, the notion of interdisciplinarity

Słowa kluczowe: nauczanie języka niemieckiego jako języka drugiego obcego, pojęcie interdyscyplinarności

1. Nauczanie języka niemieckiego w szkole a kształcenie przyszłych nauczycieli

Konferencje poświęcone tematyce kształcenia nauczycieli są dziś niezwykle popularne.15 maja 2017 roku na Uniwersytecie Pedagogicznym im. Komisji 
Edukacji Narodowej w Krakowie odbyła się konferencja „O nową jakość kształcenia nauczycieli" (Kształcenie nauczycieli - wyzwania i perspektywy), zorganizowana przez Uniwersytet Pedagogiczny i Polską Komisję Akredytacyjną ${ }^{1}$. Dyskutowano o wprowadzeniu dla nauczycieli jednolitych studiów magisterskich, uwzględniających praktyki pedagogiczne. Wiele uwagi poświęcono również propozycji upowszechnienia egzaminu zawodowego dla nauczycieli.

W kontekście tych postulatów warto rozważyć model kształcenia nauczyciela języka obcego, zwłaszcza drugiego: niemieckiego czy francuskiego. Biorąc pod uwagę kontekst społeczny i ekonomiczny kształcenia przyszłych nauczycieli, możemy śmiało postawić tezę, że model ten powinien być zgodny z założeniami kształcenia interdyscyplinarnego, co wydaje się z jednej strony zadaniem niewątpliwie trudnym, ale z drugiej - koniecznym dziś dla uczelni. Niniejszy artykuł podejmuje próbę przedstawienia modelu kształcenia: język obcy (np. język niemiecki) + drugi przedmiot oraz podkreśla rolę kształcenia interdyscyplinarnego $w$ trakcie studiów filologicznych. Zastosowanie podejścia interdyscyplinarnego w trakcie studiów na kierunku filologicznym może się w znacznym stopniu przyczynić do zdobycia kompetencji w drugim przedmiocie. Przede wszystkim jednak potrzeba wprowadzenia kształcenia dwuprzedmiotowego wynika z niełatwej sytuacji języka niemieckiego w dzisiejszej szkole.

Od lat obserwuje się wśród uczniów znaczny spadek zainteresowania językiem niemieckim. Według opracowanego przez Braunek raportu ORE o powszechności nauczania języków obcych w szkole (2013), języka niemieckiego jako przedmiotu obowiązkowego w roku szkolnym 2011/2012 uczyło się ok. $1 \mathrm{mln} 869$ tys. uczniów we wszystkich typach szkół².Liczba ta stanowiła $39 \%$ ogółu uczniów. Można powiedzieć, że fakt ten był rezultatem wprowadzenia do gimnazjum obowiązkowej nauki drugiego języka, języka niemieckiego, co daje mu wprawdzie drugą pozycję po języku angielskim, ale nie gwarantuje stabilności. W obliczu przeprowadzonej reformy trudno przewidzieć pozycję języka niemieckiego. Jest on często wybierany jako drugi język obcy od siódmej klasy szkoły podstawowej, ale też często nie jest kontynuowany w szkole średniej. Spowodowane jest to zainteresowaniem innymi językami, np. językiem hiszpańskim, poza tym uczniowie w poszczególnych regionach Polski wybierają różne języki obce nauczane jako drugie. W zachodnich rejonach kraju, ze względu na bliskość granicy niemieckiej, język niemiecki wybierany jest częściej. Według Netzwerk Deutsch (2010), liczba kursantów uczących

\footnotetext{
${ }^{1}$ http://www.up.krakow.pl/uniwersytet/aktualnosci/1885-ksztalcenie-nauczycieli-wy zwania-i-perspektywy. DW 22.10.2017.

2 http://www.bc.ore.edu.pl/Content/426/Powszechnosc_nauczania_jezykow_2011_ 2012_17.04_final.pdf. DW 11.11.2017.
} 
się języka niemieckiego w 2010 roku wynosiła 2345480 osób ${ }^{3}$, ale w 2015 spadła do $2288125^{4}$.

Język niemiecki cieszy się dużym zainteresowaniem na kursach językowych. Świadomy wybór kursu językowego przez osoby dorosłe związany jest z pracą zawodową. Polska i Niemcy to kraje ściśle ze sobą powiązane gospodarczo, społecznie i kulturowo, co znajduje odzwierciedlenie w dużej liczbie niemieckich oraz polsko-niemieckich instytucji i firm działających w Polsce. W żadnym innym kraju świata językiem niemieckim nie jest zainteresowanych tyle osób, co w Polsce. Świadomość silnej współpracy z Niemcami nie ma jednak zasadniczego wpływu na wybór języka drugiego obcego w szkole. Decydujące są tu raczej względy polityki wewnętrznej, jak: brak godzin do pensum dla nauczyciela języka francuskiego, naciski rodziców, upodobania uczniów, nastawienie do języka itp. Sam fakt, że język niemiecki jest i będzie nauczany jako drugi język obcy, powinien mieć wpływ na kształcenie nauczycieli języka drugiego obcego. Logiczne wydaje się założenie, że nauczyciel drugiego języka obcego powinien w trakcie studiów zdobyć kompetencje do nauczania drugiego przedmiotu, aby móc w miarę spokojnie funkcjonować na rynku pracy. Wiele uczelni oferuje już taką możliwość, ale dotyczy ona zdobycia uprawnień do nauczania drugiego języka. Oferta język + język jest możliwa na etapie studiów licencjackich z kontynuacją na studiach magisterskich. Nie jest jednak łatwo nauczać dwóch języków w liceum lub technikum jako przedmiotów maturalnych. Zdecydowanie łatwiejsze jest to do przeprowadzenia na poziomie szkoły podstawowej. Natomiast moduł język + język musiałby być realizowany w kształcie język niemiecki + język angielski, aby było to korzystne dla nauczyciela i jego kariery zawodowej. Jednak w obliczu nadprodukcji nauczycieli języka angielskiego, taka kombinacja może nie wpłynąć na poprawę sytuacji zawodowej nauczyciela języka niemieckiego z dodatkowym językiem angielskim. Poza tym należy zwrócić uwagę na problem jakości nauczania. Brak rodzimych modeli, badań, a często również dobrej woli wśród tworzących programy kształcenia sprawia, że nie ma dobrych wzorców przygotowania nauczycieli w zakresie dwóch przedmiotów (język obcy + drugi przedmiot). Wyjątek stanowią badania i modele kształcenia językowego w nauczaniu przed-i wczesnoszkolnym.

Przyszli nauczyciele powinni mieć możliwość zdobycia w trakcie studiów dziennych umiejętności w zakresie nauczania dwóch przedmiotów. Pomocne mogą tu być wszelkie formy doskonalenia zawodowego po studiach, ale istnieje również ryzyko, że nie przyniosą one pożądanych efektów. Germanistyka

\footnotetext{
${ }^{3}$ https://www.goethe.de/resources/files/pdf19/5759818-STANDARD.pdf. DW 05.11.2017.

${ }^{4}$ Datenerhebung 2015.https://www.dw.com/downloads/29827615/statistik-2015de utschlerner-weltweit.pdf. DW 02.11.2017.
} 
zakłada gruntowne przygotowanie studenta z przedmiotów germanistycznych. Przygotowanie psychologiczno-pedagogiczne oraz dydaktyczne realizowane jest niezależnie od studiowanego kierunku i student sam musi wybrać ten moduł, a często również sam musi za niego zapłacić. Pięć-sześć lat studiów to wystarczający czas, aby móc przygotować przyszłego nauczyciela do wejścia na rynek pracy.

Temat kształcenia nauczycieli wraca w dyskusji politycznej. W artykule Mirowskiej-Łoskopt Koniec z masowym kształceniem nauczycieli („Gazeta Prawna", 27.09.2017) ${ }^{5}$ czytamy, że Minister Nauki i Szkolnictwa Wyższego Jarosław Gowin uważa, że zbyt dużo uczelni oferuje studia dla pedagogów. Poza tym minister jest zdania, że przygotowaniem przyszłych nauczycieli powinny zajmować się tylko najlepsze uczelnie. Istotne jest, aby kształcenie to było rzeczywiście na wysokim poziomie, ale także aby uwzględniało uwarunkowania rynku pracy. Nie będzie to zadanie łatwe, bo jak w swojej książce Ekonomika oświaty w zarzq̨dzaniu szkołq pisze Jeżowski (2012:187):

Pojawił się postulat, by w stopniu licencjata kształcić tylko pedagogów ogólnie przygotowanych od strony psychologicznej, pedagogicznej i metodycznej do pracy z dzieckiem, a dopiero na tej mocnej podbudowie dawać w ramach 2-3 letnich magisterskich studiów uzupełniających wykształcenie kierunkowe do nauczania poszczególnych przedmiotów. W takiej strukturze studiów nauczyciel mógłby w czasie całej kariery zawodowej przygotować się do nauczania innych, a być może także nowych przedmiotów pojawiających się wraz z kolejnymi wyzwaniami współczesności.

Propozycja ta nie została nawet przyjęta do dyskusji przez Konferencję Rektorów Państwowych Szkół Zawodowych (KRePSZ) (zob. Jeżowski, 2012). Zgodnie z dalszym komentarzem Jeżowskiego, wydaje się to dość oczywiste, ponieważ mogłaby ona zdecydowanie „zburzyć utrwalony system i pozbawić pracy wielu wąsko wyspecjalizowanych, pracujących na kierunkach pedagogicznych w szkołach wyższych nauczycieli akademickich" (ibidem). Również Ministerstwo Nauki i Szkolnictwa Wyższego przyjęło postulat bez entuzjazmu, zasłaniając się jego niezgodnością z przyjętym przez Polskę procesem bolońskim. W gruncie rzeczy nie chodzi tu o wyrzucanie kogokolwiek z pracy, ale o zmianę kierunku myślenia. W licznych państwach z powodzeniem kształci się nauczycieli do nauczania dwóch, a nawet trzech przedmiotów (np. w Niemczech lub w Czechach). Istnieje przecież możliwość skorzystania z istniejących już przykładów i dostosowania ich do potrzeb edukacyjnych w Polsce. Warto również wspomnieć, że dawne formy przygotowania nauczycieli do pracy w szkole (np.

\footnotetext{
${ }^{5}$ https://www.google.pl/search?q=Koniec+z+masowym+kszta\%C5\%82ceniem+naucz ycieli. DW 23.10.2017.
} 
studia nauczycielskie) dawały możliwość zdobycia kompetencji do nauczania dwóch przedmiotów. Przykładami mogą być kombinacje: wychowanie fizyczne i biologia, matematyka i fizyka.

\section{Kształcenie interdyscyplinarne a przygotowanie zawodowe nauczyciela języka obcego (niemieckiego)}

Zgodnie z podejściem pedagogicznym (Kwaśnica, 2004:293) kształcenie należy rozumieć jako wyposażenie kandydatów na nauczycieli w pełne kwalifikacje zawodowe, dokształcenie jako uzupełnienie tych kwalifikacji, czyli osiągnięcie pełnego przygotowania zawodowego, zaś doskonalenie jako dostarczenie nauczycielom wiedzy i umiejętności, które wzbogacają pełne kwalifikacje zawodowe.

Czy nauczyciel po skończonych studiach może być w pełni przygotowany do wykonywania zawodu?

Zadania stojące przed nauczycielem wymagają różnych kompetencji, często kompleksowych, ponieważ nauczyciel ma do czynienia z delikatną materią uczniem. W związku z tym istotne jest, aby przyszły nauczyciel został wyposażony w bazowe kompetencje, które potem może doskonalić. W niniejszych rozważaniach przez bazowe należy rozumieć przygotowanie psychologiczno-pedagogiczne i kierunkowe w dwóch przedmiotach, realizowane w duchu interdyscyplinarnego podejścia do nauczania.

Z terminem „interdyscyplinarność” można dość często spotkać się w programach nauczania, również w programach języków obcych. Jest on jednak trudny do zdefiniowania. Jak podaje Hejmej (2007:35):

Można by powiedzieć najprościej, iż interdyscyplinarność jako współczesny fenomen sprowadza się, po pierwsze, do kwestii poznania i sposobu postrzegania świata, po drugie, w konsekwencji, do kwestii „ekonomii” wiedzy i, ostatecznie, pewnej formy władzy.

Interdyscyplinarność jest dzisiaj oczywistością, często podkreśla się ją w różnego rodzaju programach nauczania, szczególnie w odniesieniu do przedmiotów przyrodniczych, ale także humanistycznych. Na uczelniach od dawna realizowane są studia interdyscyplinarne, np. na Uniwersytecie Warszawskim indywidualne studia międzyobszarowe w obszarach nauk humanistycznych i nauk społecznych albo indywidualne studia międzyobszarowe w obszarach nauk ścisłych, nauk przyrodniczych i nauk społecznych. Rozwiązania te mają duży potencjał, ale jednocześnie sugerują kontrowersyjny charakter interdyscyplinarności w nauce (zob. Hejmej, 2007). Faktem jest, że interdyscyplinarność ma w nauce swoje miejsce. Funkcjonuje od lat 60. i 70. XX wieku. Pojawia się jako jedna z cech nauczania 
w projektach edukacyjnych (Bastian, Gudjons, 1993). Zadania realizowane w projektach mają charakter kompleksowy, w związku z czym rozwiązanie stawianych w nich problemów wymaga wiedzy i umiejętności z różnych dziedzin. Pojęcie interdyscyplinarności coraz częściej występuje także w projektach naukowych i instytucjonalnych. Klein podkreśla w swojej książce Interdisciplinarity. History, Theory, and Practice (1990), że interdyscyplinarność definiowana jest w XX wieku m.in. jako „metodologia, pojęcie, proces, sposób myślenia, filozofia” (zob. Hejmej, 2007:38).

Hermaszewski natomiast w prezentacji swojego autorstwa pt. Kształcenie interdyscyplinarne - nowa jakość kształcenia ${ }^{6}$ wyraża pogląd, że interdyscyplinarność należy rozumieć jako pewnego rodzaju współpracę między różnymi dziedzinami nauki. Każda dziedzina nauki, aby doprecyzować sformułowanie problemu, posługuje się własnymi metodami badawczymi. W celu kompleksowego rozwiązania problemu w przedmiotach muszą zostać podjęte działania zespołowe. Efekt ich wspólnej pracy często będzie miał charakter interdyscyplinarny, ponieważ powstanie nowa wiedza, która reprezentuje inne niż poszczególne dziedziny podejście do nauczania, znacznie bogatsze. Zgodnie z ideą interdyscyplinarności w nauczaniu należy jak najczęściej odchodzić od schematu: „jeden nauczyciel, jeden przedmiot, jedna godzina, jedna klasa” (ibidem). Konieczne jest odrzucenie stereotypu, zgodnie z którym nauka odbywa się przede wszystkim w szkole, pod kierunkiem jednego nauczyciela, w określonym czasie i przestrzeni. Nauczanie powinno być syntezą różnych form edukacji. Uczniom należy zagwarantować dostęp do wielu źródeł wiedzy, której dostarczają różnorodne podmioty, a zadania, które wykonują, powinny obejmować wiadomości i umiejętności z różnych dyscyplin (zob. Hermaszewski, 2013).

Kształcenie interdyscyplinarne ma zatem wiele zalet. Warto zastanowić się nad tym, w jakim stopniu stosowane jest ono w polskich szkołach. Zagadnienie to zostało uwzględnione w badaniach potrzeb i oczekiwań nauczycieli, zleconych przez Centrum Nauki Koperniki przeprowadzone przez Pracownię Badań i Innowacji Społecznych „Stocznia” w maju 2009 roku. W badaniu brali udział nauczyciele szkół podstawowych i gimnazjów.

Wyniki badania przedstawiły Krzyżanowska i Wiśnicka w raporcie $W y$ korzystanie eksperymentów i metod aktywizujqcych w nauczaniu - problemy i wyzwania. Raport z badań (2009: 38-40). Cel projektu był związany z potrzebą skutecznej komunikacji oferty Centrum Nauki Kopernik oraz z dopasowaniem założeń ofertowych do oczekiwań zarówno nauczycieli, jak i uczniów. W raporcie wiele miejsca zajmują opisy, w jaki sposób nauczyciele pracują z uczniami. Pojawiło się także zagadnienie interdyscyplinarności - czy w ogóle występuje

6 http://hermaszewski.glogow.pl/wpcontent/uploads/2013/12/Prezentacja-20.11.2013. pdf. DW 29.09.2017. 
i jak jest realizowane. Przeprowadzono z nauczycielami liczne wywiady, z których wynikało, że interdyscyplinarność nauki istnieje w szkole jedynie w sferze teorii, często tylko w deklaracjach nauczycieli. Rzadko podejmowane były próby podejścia interdyscyplinarnego, często w czasie zajęć dodatkowych, przez nieliczną grupę nauczycieli, którzy czuli potrzebę ciągłego rozwijania swoich umiejętności. We wnioskach stwierdzono, że idea interdyscyplinarności była stosowana podczas lekcji sporadycznie. Wynikało to z braku zaangażowania ze strony nauczycieli oraz niedostatecznych kompetencji. Mimo że badania te dotyczyły przedmiotów przyrodniczych, to jednak stanowią dowód na to, że na poziomie akademickim nie kształtuje się w przyszłych nauczycielach określonych umiejętności interdyscyplinarnych. Dzięki podejściu interdyscyplinarnemu uczy się komunikacji, współpracy i myślenia krytycznego, kształtuje się umiejętności rozwiązywania problemów, wdraża się do podejmowania inicjatyw oraz do samodzielności, pobudza się do kreatywności i innowacyjności. Potrzeba realizacji form kształcenia interdyscyplinarnego na wyższych uczelniach jest zatem niezaprzeczalna.

W kontekście rozwoju podejścia interdyscyplinarnego na kierunkach filologicznych należy zwrócić uwagę na dwa aspekty: scalenia wiedzy przedmiotowej z wiedzą dydaktyczną oraz zdobycie kompetencji do nauczania drugiego przedmiotu. Pierwszy aspekt dokładnie omawia w swoim artykule Korelacja międzyprzedmiotowa w programach kształcenia nauczycieli języków obcych Sikorska (2009: 184). Autorka wyraźnie podkreśla potrzebę znajomości podstaw dydaktyki języków obcych przez nauczycieli akademickich wykładających poszczególne przedmioty filologiczne:

Scalanie wiedzy pod kątem potrzeb zawodowych absolwentów powinno się odbywać w ramach wszystkich przedmiotów. W tym celu konieczna jest znajomość podstaw dydaktyki języków obcych przez nauczycieli akademickich zaangażowanych w proces kształcenia. Dzięki temu możliwe jest tworzenie powiązań pomiędzy różnymi zakresami wiedzy, np. przez wskazanie przy omawianiu kierunków językoznawczych na ich znaczenie dla powstawania metod nauczania języków obcych (ibidem).

Korelacja zajęć dydaktycznych i językowych wpłynęłaby w znacznym stopniu na możliwość powiązania teorii z praktyką w trakcie nauki własnej studenta. I jak dalej pisze Sikorska:

(...) stwarza również możliwość fachowej analizy i oceny stosowanych procedur metodycznych oraz doświadczanego stylu nauczania. Nawiązanie do tej wiedzy w trakcie zajęć $z$ dydaktyki szczegółowej znacząco przyśpiesza opanowanie materiału nauczania oraz umożliwia dokonywanie syntez z uwzględnieniem związków interdyscyplinarnych, niezbędnych do całościowego spojrzenia na procesy zachodzące w obrębie układu glottodydaktycznego (ibidem:185). 
Tego typu kształcenie znacznie przyczynia się do rozwoju umiejętności powiązania określonych zagadnień przynajmniej z dwóch dyscyplin i wpływa na możliwość opanowania kompetencji do nauczania drugiego przedmiotu. Należy przy tym zwrócić uwagę na zastosowanie odpowiednich metod, np. CLIL, czyli zintegrowanego nauczania przedmiotowo-językowego, którego elementy zdecydowanie sprzyjają rozwojowi podejścia interdyscyplinarnego. Nauczanie to sprawdza się w trybie edukacji dwujęzycznej, zwłaszcza przez takie jego aspekty jak: rozwój wiedzy interkulturowej, przygotowanie do życia w warunkach integracji europejskiej, ogólny rozwój kompetencji językowej języka docelowego, nabywanie terminologii fachowej w języku docelowym, rozwój indywidualnego repertuaru strategii uczenia się. Zdecydowanie powinno mieć ono zastosowanie w kształceniu nauczyciela języka obcego. Tematami i treściami danego przedmiotu studenci powinni zajmować się z pespektywy nie tylko własnego kraju, ale przede wszystkim z perspektywy kraju, w którego języku odbywają się zajęcia. Dzięki temu rozwijane są kompetencje międzykulturowe.

Często podkreślana jest rola nauczyciela języka obcego jako mediatora interkulturowego (Mackiewicz 2009:72). Postuluje się, aby treści przedmiotów kulturoznawczych znacznie wykraczały poza obowiązujący kanon wiedzy i były oparte na indywidualnych zainteresowaniach i pracach badawczych wykładowców, co umożliwiłoby prowadzenie zajęć specjalizacyjnych, autorskich, w których prowadzący wykorzystywałby swoje materiały, strony internetowe, blogi, zasoby zgromadzone na platformie Moodle. Zaleca się nowe zdefiniowanie nauczania praktycznej znajomości języka „jako propedeutyki literatury i kultury" (ibidem), co w dość naturalny sposób wymusza interdyscyplinarny charakter zajęć. Wśród postulatów znalazły się również wnioski dotyczące potrzeby podniesienia wśród studentów świadomości kulturowej dotyczącej ich ojczystego kraju i języka.

Mediator powinien nie ograniczać się tylko do podręcznika kursowego, lecz również szukać dodatkowych źródeł informacji kulturowej, zarówno o kulturze docelowej, jak i wyjściowej, tworzyć materiały i zadania z użyciem tych źródeł, wykorzystywać w tym celu najnowsze technologie (jak np. Internet, programy multimedialne etc.) oraz promować wśród uczniów nawiązywanie i podtrzymywanie kontaktów z rówieśnikami z innych krajów poprzez np. e-maile, GG, skype. Mediator interkulturowy powinien wspierać rozwój autonomii uczniów, dobierając odpowiednie tematy, materiały, sposoby uczenia się i formy pracy (np. praca nad projektem etnograficznym, portfolio) oraz wychodzić poza ramy swojego przedmiotu i wspólnie z nauczycielami innych przedmiotów (w ramach ścieżek międzyprzedmiotowych) przybliżać uczniom tajniki kultury obcej i własnej, motywując ich tym samym do samodzielnej pracy (Mihułka, 2009:66). 
Podany przez Mihułkę zespół zadań mediatora interkulturowego wyraźnie świadczy o potrzebie sięgania przez niego w trakcie studiów po instrumenty podejścia interdyscyplinarnego. Wykorzystanie nowoczesnych technologii, tworzenie materiałów o kulturze docelowej, jak i wyjściowej, nie będą możliwe bez wypracowanego podczas studiów modelu działań interdyscyplinarnych. Nauczyciel pełniący rolę mediatora interkulturowego powinien umiejętnie łączyć wiedzę z literatury i kultury kraju docelowego, aby za pomocą środków językowych przekazać treść i wytłumaczyć fenomen budowania wzajemnych związków między kulturami. Niewystarczające jest przeprowadzenie seminarium na temat obecności tematyki polskiej w prasie niemieckiej, wyeksponowanie tylko treści, które się w niej pojawiają. Niezbędne wydaje się przedyskutowanie wyboru określonej tematyki, wskazanie, jaki jest jej kontekst społeczny, i zastanowienie się, czy niesie ona ze sobą szansę na wzajemne porozumienie. Poszukiwanie punktów wspólnych oraz dyskusja nad odmiennym sposobem patrzenia na daną tematykę (np. fala emigracji w Niemczech), przy jednoczesnym sięganiu do wiedzy historycznej i odwołaniu się do analizy społeczno-politycznej, to już instrumenty podejścia interdyscyplinarnego.

\section{Rozwój kompetencji w zakresie drugiego przedmiotu-propozycje własne}

"Od nauczyciela wymaga się, aby był ekspertem, wychowawcą, pośrednikiem kulturowym, organizatorem, moderatorem i doradcą, ewaluatorem, jak również innowatorem, badaczem i refleksyjnym praktykiem" (Sikorska, 2009:179). Wszystkie te role wymagają od programów studiów uwzględnienia korelacji międzyprzedmiotowej. Rozwój podejścia interdyscyplinarnego na jednym kierunku nie tylko powinien wpłynąć na sposób uczenia się studenta $w$ trakcie studiów, ale także powinien pomóc mu w zdobyciu kompetencji do nauczania drugiego przedmiotu. Jak już wyżej wspomniano, nauczyciel języka obcego, niemieckiego znajduje się $\mathrm{W}$ dość trudnej sytuacji na rynku pracy. $\mathrm{W}$ dobie dyskusji nad programem kształcenia nauczycieli i otwartych przygotowań Ministerstwa Nauki i Szkolnictwa Wyższego do zmian (Opracowanie modelowych programów kształcenia nauczycieli w ramach działania 3.1 Kompetencje w szkolnictwie wyższym) należy szczególnie podkreślić potrzebę kształcenia dwuprzedmiotowego. Przygotowywane przez ministerstwo programy mają uwzględniać innowacyjne metody pedagogiczne (learning-by-doing, design thinking), rozwój kompetencji społecznych oraz propozycje w zakresie rozwiązywania problemów wychowawczych, a także zastosowanie narzędzi cyfrowych?

\footnotetext{
${ }^{7}$ http://www.nauka.gov.pl/projekty-i-inicjatywy/opracowanie-modelowych-program ow-ksztalcenia-nauczycieli-w-ramach-dzialania-3-1. DW 23.11.2017.
} 
Sensowny wydaje się więc dla potrzeb szkoły podstawowej zaproponowany przez autorkę niniejszego artykułu model: język obcy (np. język niemiecki) + informatyka w zakresie podstawowym. Model ten mógłby być realizowany na poziomie 4-letnich studiów licencjackich, a treści nauczania w obu przedmiotach powinny być zgodne z podstawą programową na poziomie szkoły podstawowej. Model kształcenia językowego jest już wypracowany. Należy bliżej przyjrzeć się drugiemu przedmiotowi. Od czwartej klasy zajęcia z informatyki mają charakter bardziej formalny, uczeń prowadzi własne realizacje w postaci programów lub czynności wykonywanych w innych programach. Rozwija podejście algorytmiczne przy rozwiązywaniu sytuacji problemowych z różnych dziedzin, poznaje podstawowe pojęcia informatyczne, zapoznaje się z wizualnym lub tekstowym językiem programowania, kształtuje myślenie komputacyjne. Student germanistyki powinien mieć możliwość pozyskania dodatkowych kompetencji w zakresie uczenia informatyki na poziomie szkoły podstawowej, ponieważ i tak jednym z wymogów współczesnego kształcenia i doskonalenia nauczycieli jest przygotowanie do posługiwania się nowoczesną technologią informacyjną i komunikacyjną. Technologie cyfrowe są częścią zajęć informatycznych. Zajęcia te nie tylko mają na celu przygotować do prowadzenia informatyki na poziomie szkoły podstawowej, ale także powinny pokazywać możliwość integracji technologii w dydaktyce przedmiotowej (dydaktyce języka obcego) i co za tym idzie kształtować podejście interdyscyplinarne. Cyfrowa edukacja zwiększa efektywność nauczania języka obcego a zatem należy ją prowadzić na zajęciach językowych. Wymagane umiejętności posługiwania się technologią informacyjną i komunikacyjną powinny być wzbogacone o podstawy informatyki, szczególnie w zakresie podstaw programowania i rozwiązywania problemów z wykorzystaniem komputera i innych urządzeń cyfrowych. Opcja związana z możliwością wyboru informatyki na poziomie szkoły podstawowej może być dostępna dla studentów filologii obcych zainteresowanych poszerzeniem swoich kompetencji i powinna funkcjonować jako dodatkowy moduł. Po jego zrealizowaniu przyszli nauczyciele mieliby prawo nauczania informatyki na poziomie szkoły podstawowej, przede wszystkim od klasy czwartej do klasy ósmej, i zdecydowanie rozwinęliby swoje umiejętności z dziedziny wykorzystania technologii informacyjnej i komunikacyjnej na lekcji języka obcego. Poprzez dodatkowy przedmiot- informatykę dla szkół podstawowych - proponowany przez Krajkę (2009:204) profil oczekiwanych umiejętności komputerowych absolwenta filologii „(nauczyciel/moderator nauczania wspomaganego komputerowo, twórca cyfrowych materiałów glottodydaktycznych lub połączenie obu tych ról) oraz przewidywanego obszaru kształcenia (nauczanie wspomagane komputerowo w klasie tradycyjnej, nauczanie na odległość/mieszane czy nauczanie prowadzone we współpracy)" stałby się realistyczny. 
Druga propozycja dotyczy przedmiotu nauczanego w szkole średniej. Chodzi o podstawy przedsiębiorczości, które realizowane w postaci dodatkowego modułu dawałyby uprawnienia do nauczania tego przedmiotu w liceum i technikum. W nowej podstawie programowej przedmiot ten powinien dać uczniowi wiedzę w zakresie ekonomicznych podstaw konkurencyjnych i przedsiębiorczych zachowań na rynku. Ma on również na celu przygotowanie do aktywności społecznej i gospodarczej. Przedsiębiorczość jako kluczowa kompetencja obejmuje szereg interesujących treści, w tym:

- Posługiwanie się elementarnymi pojęciami z zakresu podstaw przedsiębiorczości.

- Rozumienie istoty przedsiębiorczości oraz poznanie jej roli w gospodarce i życiu człowieka.

- Wyjaśnianie mechanizmów funkcjonowania gospodarki rynkowej i powiązań między jej podmiotami.

- Poznanie roli państwa w procesach gospodarczych.

- Zaznajomienie się z prawami i instytucjami chroniącymi konsumenta.

- Rozumienie roli pieniądza i rynków finansowych w gospodarce, funkcjonowaniu przedsiębiorstw i życiu człowieka.

- Poznanie rodzajów podatków oraz ich wpływu na budżety państwa, przedsiębiorstw i gospodarstw domowych.

- Rozumienie znaczenia ubezpieczeń w działalności gospodarczej i życiu człowieka.

- Poznanie funkcjonowania rynku pracy oraz zasad aktywnego poszukiwania pracy i przygotowania się do rozmowy kwalifikacyjnej.

- Zaznajomienie się z prawami oraz obowiązkami pracownika i pracodawcy.

- Poznanie zasad funkcjonowania przedsiębiorstwa w gospodarce rynkowej, form organizacyjno-prawnych, innowacyjnych modeli biznesowych i procedury rejestracji działalności gospodarczej.

- Rozumienie zasad zarządzania, roli marketingu oraz społecznej odpowiedzialności w funkcjonowaniu przedsiębiorstwa ${ }^{8}$.

Przedstawione treści stwarzają możliwość korelacji z zajęciami prowadzonymi często na filologii germańskiej w ramach Wirtschaftsdeutsch. Niektóre filologie, ze względu na późniejszą pracę absolwentów w korporacjach, wprowadzają seminaria o zagadnieniach gospodarczych w Niemczech czy formach prawnych funkcjonowania przedsiębiorstw itp. Ta kombinacja umożliwia podejmowanie działań interdyscyplinarnych: np. porównawczych - sytuacja ekonomiczna rodziny polskiej a rodziny niemieckiej, formy oszczędzania i inwestowania oraz ich ocena z punktu widzenia ryzyka i przewidywanych zysków,

\footnotetext{
${ }^{8} \mathrm{https} / / /$ men.gov.pl/wp-content/uploads/2017/04/przedsiebiorczosc-liceum-i-techn ikum.pdf. DW 01.10.2017.
} 
przeprowadzenie symulowanej inwestycji. Prowadzenie tego rodzaju zajęć przez nauczyciela germanistę, wyposażonego w wiedzę z zakresu przedsiębiorczości, stwarza również niepowtarzalną okazję do realizowania z uczniami projektów edukacyjnych o funkcjonowaniu rynku czy przedsiębiorstw. Na zajęciach projektowych, ze względu na ich interdyscyplinarny charakter, język obcy, niemiecki jest często instrumentem w przekazywaniu treści specjalistycznych. W klasach dwujęzycznych, z językiem niemieckim, przedmiot podstawy przedsiębiorczości może być prowadzony w języku docelowym.

\section{Podsumowanie}

Powyższe uwagi i przedstawione dwie propozycje modeli kształcenia nauczyciela w dwóch przedmiotach mogą przynieść duże korzyści zarówno studentom (przyszłym nauczycielom), uczniom, jak i wykładowcom akademickim. W trakcie studiów filologicznych student opanuj umiejętności związane z wykorzystaniem instrumentów podejścia interdyscyplinarnego w nauczaniu języka, przekazywaniu treści interkulturowych, pełnieniu roli doradcy i mediatora między kulturą własnego kraju a kraju docelowego. Kompetencja uzyskana w drugim przedmiocie może się przyczynić do rozwoju wiedzy i umiejętności praktycznych studenta, a także może stanowić okazję do sięgania po literaturę przedmiotu w języku obcym np. w trakcie pisania pracy dyplomowej. Uczeń nauczany przez dobrze przygotowanego nauczyciela, posiadającego oprócz kompetencji filologicznej również umiejętności w zakresie drugiego przedmiotu, pozna instrumenty podejścia interdyscyplinarnego, które będzie mógł wykorzystać przy realizacji zadań w szkole. Przykład mogą stanowić wymienione już w artykule projekty edukacyjne przeprowadzane $w$ ramach ścieżki międzyprzedmiotowej. Natomiast wykładowcy akademiccy zyskają możliwość pracy ze studentem o szerszych horyzontach, w większym stopniu zmotywowanym do studiowania.

Obecnie potrzebne jest inne spojrzenie na kształcenie nauczyciela języka obcego, szczególnie drugiego. Nie można pomijać milczeniem tak istotnych faktów, jak dobre przygotowanie studenta do pracy w szkole czy do funkcjonowania na trudnym rynku pracy. Oczywiste jest, że przy okazji takiej dyskusji wielu przeciwników kształcenia dwukierunkowego, np. w modułach zaprezentowanych w artykule, posłuży się argumentem wprowadzania chaosu w kształceniu czy brakiem odpowiedniej kadry. Konieczność przeprowadzenia reformy w zakresie edukacji nauczycieli daje okazję do zwrócenia uwagi na rangę tego zawodu oraz znaczenie dla kształtowania społeczeństwa, a także na wpływ tej profesji na rynek pracy. Należy więc wręcz apelować o modyfikację kształcenia w kierunku dwóch przedmiotów, zwłaszcza na poziomie szkoły podstawowej. W związku z tym postulatem być może należałoby wydłużyć okres 
studiowania np. na poziomie licencjatu do czterech lat, ewentualnie mocno zmodyfikować programy nauczania. Niewątpliwie korelacja przedmiotowa, kształtowanie w wykładowcach i studentach podejścia interdyscyplinarnego poprzez odpowiednie seminaria i działania edukacyjne, może przynieść znaczną poprawę w kształceniu nauczyciela. Za Klochem (2007) należy powiedzieć:

Interdyscyplinarność jest dziś i modą, i koniecznością. Modą jest wówczas, gdy pojawia się jako hasło reklamujące wyższą prywatną szkołę humanistyczną („U nas uczymy interdyscyplinarnie"). Ale interdyscyplinarność w dzisiejszej humanistyce jest także koniecznością, a to dlatego, że ta tendencja dominuje dziś w myśleniu o człowieku i kulturze, i dzieje się tak już od dłuższego czasu.

Interdyscyplinarność może zmienić sposób nauczania na kierunkach filologicznych i dać perspektywę na zdobycie kompetencji w drugim przedmiocie nauczanym w polskich szkołach. Niniejsze rozważania mogą stanowić początek istotnej dyskusji nad modelami kształcenia interdyscyplinarnego, szczególnie nauczycieli języków obcych drugich.

\section{BIBLIOGRAFIA}

Bastian, J. i Gudjons, H. (red.). 1993. Das Projektbuch II. Hamburg: Bergmann Helbig. Braunek, A. 2013. Raport ORE. Powszechność nauczania języków obcych w roku szkolnym 2011/2012.URL: http://www.bc.ore.edu.pl/Content/426/Powsze chnosc_nauczania_jezykow_2011_2012_17.04_final.pdf. DW 10.11.2017.

Deutsch als Fremdsprache weltweit. Datenerhebung 2015. URL: http://www .dw.com/downloads/29827615/statistik-2015-deutschlerner-weltweit.pdf. DW 02.11.2017.

Hejmej, A. 2007. „Interdyscyplinarność i badania komparatystyczne” (Rozprawy i Szkice). Wielogłos. Pismo Wydziału Polonistyki Uniwersytetu Jagiellońskiego, 1:35-53.URL: http://www.ejournals.eu/sj/index.php/ Wieloglos/article/view/35-53/163. DW 10.11.2017.

Hermaszewski, J. 2013. Kształcenie interdyscyplinarne -nowa jakość kształcenia (Prezentacja). URL: http://hermaszewski.glogow.pl/wpcontent/upl oads/2013/12/Prezentacja-20.11.2013.pdf. DW 29.09.2017.

Jeżowski, A. 2012. Ekonomika oświaty w zarzq̨dzaniu szkołq. Warszawa: Wolters Kluwer.

Klein, J.T. 1990. Interdisciplinarity. History, Theory, and Practice. Detroit, MI: Wayne State University Press.

Kloch,Z. 2007. Interdyscyplinarność w naukach społecznych i humanistycznych - możliwości i ograniczenia (Tekst wygłoszony na seminarium Wydziału 
I Nauk Społecznych PAN i Instytutu Filozofii i Socjologii PAN, 21.11.2007). URL:http://www.obta.uw.edu.pl/pl/node/61. DW 12.11.2017.

Krajka, J. 2009. „Nauczyciel języków obcych wczoraj, dziś i jutro - kształcenie informatyczne nauczycieli w erze Internetu 2.0". (w:) Nauczyciel języków obcych dziś i jutro. (red. M. Pawlak, A. Mystkowska-Wiertelak i A. Pietrzykowska). Poznań: Wydział Pedagogiczno-Artystyczny w Kaliszu, s. 199-208.

Krzyżanowska, Ł. i Wiśnicka, M. 2009. Wykorzystanie eksperymentów i metod aktywizujqcych w nauczaniu - problemy i wyzwania. Raport z badań. Centrum Nauki Kopernik, Warszawa, s. 38-40.

Kwaśnica, R. 2004. „Wprowadzenie do myślenia o nauczycielu”. (w:) Pedagogika (red. Z. Kwieciński i B. Śliwerski). Warszawa: PWN, s. 291-319.

Mackiewicz, M. 2009. „Nauczyciel języka obcego jako kulturoznawca i mediator interkulturowy. Kilka refleksji i postulatów z perspektywy germanistycznej". (w:) Nauczyciel języków obcych dziś i jutro. (red. M. Pawlak, A. MystkowskaWiertelak i A. Pietrzykowska). Poznań: Wydział Pedagogiczno-Artystyczny w Kaliszu, Poznań: Wydział Pedagogiczno-Artystyczny w Kaliszu, s. 71-82.

Mihułka, K. 2009. „Mediator interkulturowy - nowa rola nauczyciela języków obcych". (w:) Nauczyciel języków obcych dziś i jutro. (red. M. Pawlak, A. Mystkowska-Wiertelak i A. Pietrzykowska). Poznań: Wydział PedagogicznoArtystyczny w Kaliszu, s. 61-70.

Mirowska-Łoskot, U. "Koniec z masowym kształceniem nauczycieli”. Gazeta Prawna, 27.09.2017. URL:https://www.google.pl/search?q=Koniec+z+ masowym+kszta\%C5\%82ceniem+nauczycieli. DW 23.10.2017.

Netzwerk Deutsch: Statistische Erhebungen 2010. URL: https://www.goethe.d e/resources/files/pdf19/5759818-STANDARD.pdf. DW 07.11.2017.

Projekt. Podstawy przedsiębiorczości liceum ogólnokształcqce i technikum po szkole podstawowej. URL:https://men.gov.pl/wp-content/uploads/ 2017/04/przedsiebiorczosc-liceum-i-technikum.pdf. DW 08.11.2017.

Sikorska, M. 2009. „Korelacja międzyprzedmiotowa w programach kształcenia nauczycieli języków obcych". (w:) Nauczyciel języków obcych dziś i jutro. (red. M. Pawlak, A. Mystkowska-Wiertelak i A. Pietrzykowska). Poznań: Wydział Pedagogiczno-Artystyczny w Kaliszu, s. 179-188. 